\title{
Nutritional Quality of Three Cobitid Fishes of Manipur, India: With Special Reference to Essential Mineral Elements
}

\author{
M. Shantosh ${ }^{1 *}$ and Ch. Sarojnalini ${ }^{2}$ \\ ${ }^{1}$ Centre of Advance Study in Life Sciences, Fishery Laboratory, Manipur University, Canchipur-795003 Manipur, India \\ ${ }^{2}$ Centre of Advance Study in Life Sciences, Fishery Laboratory, Manipur University, Canchipur-795003 Manipur, India
}

*Corresponding author: sarojnalinich@gmail.com, Tel.: 9436891730

Available online at: www.isroset.org

Received: 13/Mar/2018, Revised: 24/Mar/2018, Accepted: 20/Apr/2018, Online: 30/Apr/ 2018

\begin{abstract}
The study were carried out to determine the proximate composition and essential mineral elements of three Cobitid fish species of Manipur, India viz. Lepidochephalichthys guntea, Pangio pangia and Syncrossus berdmorei. Moisture $(76.12 \pm 0.05 \%)$ were significantly $(\mathrm{p}<0.05)$ higher in Pangio pangia. In Syncrossus berdmorei, significantly $(\mathrm{p}<0.05)$ higher protein $(22.57 \pm 0.00 \%)$ and lipid $(12.93 \pm 0.66 \%)$ were recorded. Whereas, ash $(3.23 \pm 0.07 \%)$ was significantly higher in Lepidochephalichthys guntea. Macro elements $\mathrm{Ca}, \mathrm{Mg}, \mathrm{K}$ and $\mathrm{Na}$ were abundantly found in all the fish studied and micro elements $\mathrm{Mg}$, $\mathrm{Ni} \mathrm{Cu}, \mathrm{Zn}$, and $\mathrm{Fe}$ were also found in adequate amount. Results from the analysis revealed that macro elements viz. $\mathrm{Ca}(2150 \pm 8.71 \mathrm{mg} / 100 \mathrm{~g})$ and $\mathrm{Mg}(131.7 \pm 2.05 \mathrm{mg} / 100 \mathrm{~g})$ and micro elements viz. $\mathrm{Na}(112.5 \pm 0.06 \mathrm{mg} / 100 \mathrm{~g}), \mathrm{Ni}(2.25 \pm 0.02$ $\mathrm{mg} / 100 \mathrm{~g}), \mathrm{Cu}(0.47 \pm 0.007 \mathrm{mg} / 100 \mathrm{~g})$ and $\mathrm{Zn}(3.05 \pm 0.014 \mathrm{mg} / 100 \mathrm{~g})$ were found significantly $(\mathrm{p}<0.05)$ higher in Lepidochephalichthys guntea. Whereas K $(90.81 \pm 1.14 \mathrm{mg} / 100 \mathrm{~g})$ and $\mathrm{Mn}(1.26 \pm 0.01 \mathrm{mg} / 100 \mathrm{~g})$ were significantly $(\mathrm{p}<0.05)$ higher in Syncrossus berdmorei among the fishes studied. Fe content was recorded significantly $(\mathrm{p}<0.05)$ higher than other micro elements and found highest in Syncrossus berdmorei $(28.61 \pm 0.10 \mathrm{mg} / 100 \mathrm{~g})$ amoung the fish studied. From the above analysis it has been reveal that all the fishes were good sources of protein, lipid, ash and mineral contents which can provide high nutritive value for human diet.
\end{abstract}

Key words: Proximate, macro and micro elements, nutritive value, human diet.

\section{INTRODUCTION}

Cobitid fishes are usually small, slender fishes which are more abundant and diverse in Southeast Asia. They are distinguished by the present of an erectile, moveable, bifid suborbital spine. Most species are elongated, some are somewhat flattened or at least have a flat belly which indicate a life on or in river bottom. Some are borrow into sand, mud and detritus. The species are mostly found in rivers, lakes or swamps, they feed on small animals in the bottom sediment [18].

The family Cobitids are amoung the Small Indigenous Fishes (SIS). Many SIS are less than $10 \mathrm{~cm}$ or 3.9 inches in length and they are consumed as a whole [29]. These fishes have short life cycle and can be grow in all types of inland water bodies. North East India owing to its topographical features provides an ideal habitat for various endemic small fishes. As many as 47 genus of small fishes are recorded from North East India out of this 40 genus are found in Manipur [37]. In Manipur, this small fishes are abundant in river, beels, streams, canals and ponds. Due to overfishing, destruction of their habitats and feeding ground, some of the small fishes are on the verge of extinction. So, there is an urgent need for the conservation and proper management to increase the productivity of these small fishes.

Small Indigenous Fishes are consuming as a whole which provide an excellent source of micronutrients. Whole small fish with bones are an extremely Ca rich food [33] and in some species, vitamin A is richly accumulated around their eyes and viscera [24]. Many of the elements are taking part in various metabolic processes and are known to be indispensible to all living things. Among the elements the most important mineral elements are $\mathrm{Ca}, \mathrm{Na}, \mathrm{P}, \mathrm{Fe}, \mathrm{K}, \mathrm{Cl}$ and many are also needed in trace amount. The deficiency of these important nutritional minerals induces many malfunction as it reduce productivity and causes diseases such as inability of blood clot, osteoporosis, anaemia, etc. Roos et al., 2007 [23] have reported that vitamin A, calcium, iron and zinc are abundantly present in commonly consumed small fishes of Bangladesh. In Bangladesh small fishes play a pivotal role as rich sources of vitamin $\mathrm{A}$ and to combat vitamin A deficiency among the children [29]. In addition to the nutritional values, it is crucial to say that Small 
Indigenous Fishes plays a vital role in life and economy of vast majority of the fisherman community and poor rural. It is well accepted throughout the world that fish are the good source of protein and other important mineral elements for the maintenance of healthy body [1]. Compare to other source of protein, fish protein are known for the excellent source of protein from their amino acid composition and protein digestibility [22].

In Manipur, any types of big or small fishes are consumed in fresh or process form. Small cobitid fishes viz Syncrossus berdmorei and Lipidocephalus irrorata endemic in this area are highly esteemed among the people and also provide essential nutrients among the peoples of Manipur [4]. The measurement of proximate profiles such as moisture, lipid, protein content, ash content, etc is often necessary to ensure that they meet the dietary requirements and commercial specification [13]. So, the aim of the current study was to investigate proximate composition, macro and micro elements of Small Indigenous Fishes of Manipur as an extension to the previous worker on this field and to provide knowledge of nutritional value prior to human consumption.

Rest of the paper is organized as follows, Section I contains the introduction, Section II elaborate the related work of nutritional aspects of fishes of various countries around the world, section III explain the various methodology of different nutritional aspects of the fishes studied and statistical analysis, Section IV describes results and discussion on various nutritional qualities that has reveal after the analysis of the fishes studied and Section V concludes research work with future directions).

\section{RELATED WORK}

There are some reports on the biochemical composition and nutritional qualities of small fishes. Some of the related work done by various worker are Sakuntala et al., 1997 [29] studied on the role of Small Indigenous Fish species in food and nutrition security in Bangladesh, Larsen et al., 2000 [33] has reported on small fishes as a rich sources of calcium, Roos et al., 2007 [23] have describe about the role of fish in food based strategies to combat Vitamin A and mineral Deficiencies in Developing countries, Saronalini 2010 [4] have reported on Nutritive value of two indigenous Cobitid fishes of Manipur, Abdul and Sarojnalini 2012 [11] have done on the nutrition aspects of Fresh and Smoked dried hill stream fishes of Manipur. C. Sarojnalini and W. Sarjubala, 2014 [5] have reported on various nutritional aspects of fresh and cooked small indigenous fishes of Manipur.

\section{MATERIAL AND METHOD}

\section{Sample collection:}

Cobitid fishes viz Lepidochephalichthys guntea (Halminton, 1822), Pangio pangia (Halminton, 1822) and Syncrossus berdmorei (Blyth, 1860) of Manipur were collected and shown in fig 1 to 3 . Respective collecting sites and total length-weight were shown in Table 1 and Fig 4 respectively. The collected fish sample consists of six samples each was brought in fresh with proper care in cold chain to Fishery laboratory, Department of Life Science, Manipur University and washes immediately in running tap water and fishes are taken as a whole for undergoing various analyses.

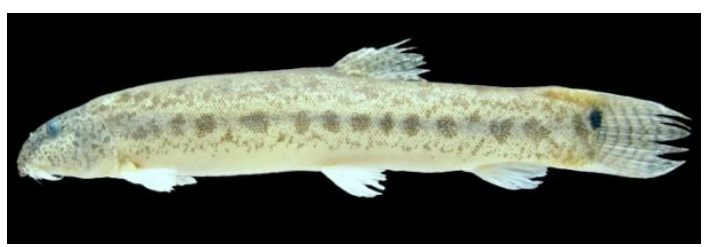

Fig 1: Lepidochephalichthys guntea

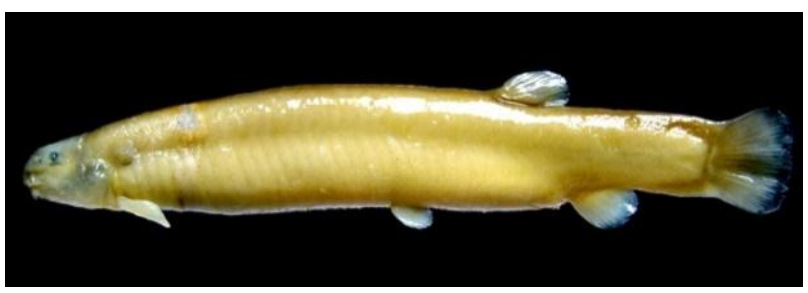

Fig 2: Pangio pangia

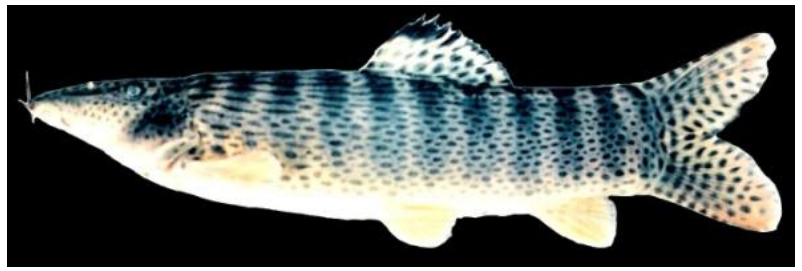

Fig 3: Syncrossus berdmorei 


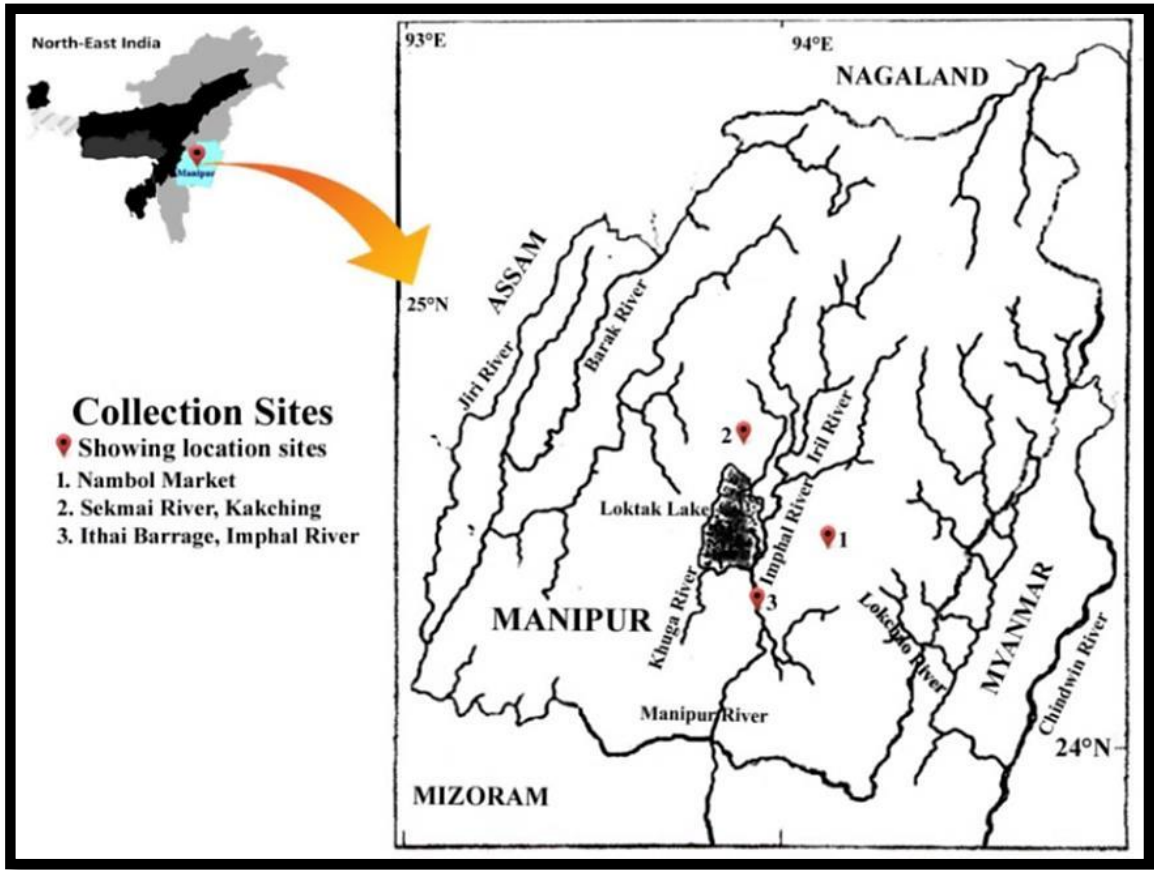

Fig 4: Map showing the collection sites of the fish samples

Table 1: The respective collection sites and length- weight of five Small Indigenous Fishes of Manipur.

\begin{tabular}{|c|c|c|c|c|c|c|}
\hline Species & Local name & Collection site & GPS Location & $\begin{array}{l}\text { Total Lengtl } \\
\text { (cm) }\end{array}$ & Weight (gm & $\begin{array}{l}\text { IUCN Red list } \\
\text { Status }\end{array}$ \\
\hline $\begin{array}{l}\text { Lepidochephalichthy } \\
\text { s guntea }\end{array}$ & Ngakijou & Nambol Market & $\begin{array}{l}24^{\circ} 43^{\prime} 01.49^{\prime \prime} \\
\mathrm{N} \\
94^{\circ} 50^{\prime} 09.88^{\prime \prime} \mathrm{E}\end{array}$ & $7.93 \pm 0.31$ & $3.12 \pm 0.32$ & Least concern \\
\hline Pangio pangia & Nganap & Nambol Market & $\begin{array}{l}24^{\circ} 43^{\prime} 01.49^{\prime}, \\
\mathrm{N} \\
94^{\circ} 50^{\prime} 09.88^{\prime}, \mathrm{E}\end{array}$ & $6.90 \pm 0.15$ & $1.42 \pm 0.06$ & Least concern \\
\hline $\begin{array}{l}\text { Syncrossus } \\
\text { berdmorei }\end{array}$ & $\begin{array}{l}\text { Sareng- } \\
\text { Khoibi }\end{array}$ & $\begin{array}{l}\text { Sekmai River, } \\
\text { Kakching } \\
\text { Imphal River, } \\
\text { Ithai Barrage }\end{array}$ & $\begin{array}{l}24^{\circ} 28^{\prime} 05.79^{\prime}, \\
\mathrm{N} \\
94^{\circ} 59^{\prime} 44.54^{\prime \prime} \mathrm{E} \\
24^{\circ} 25^{\prime} 31.43^{\prime \prime}, \\
\mathrm{N} \\
94^{\circ} 50^{\prime} 16.87^{\prime \prime} \mathrm{E}\end{array}$ & $13.76 \pm 0.14$ & $\begin{array}{l}17.92 \pm 0.6 \\
1\end{array}$ & $\begin{array}{l}\text { Near } \\
\text { threatened }\end{array}$ \\
\hline
\end{tabular}

Values are mean of three replicate.

\section{Proximate composition:}

Moisture content was determined by hot air oven method [2] at $60^{\circ} \mathrm{C}$ till a constant weight is obtained. The loss in weight was express in percentage in wet weight of the sample. Total Nitrogen content was determined by modified micro- Kjeldahl method [2]. The sample were subjected to digestion, Nesslerization and finally measured by using UV-1800 UV-Spectrophotometer, Shimadzu. Total protein value was obtained by multiplying the total nitrogen value with 6.25 . Total lipid was also extracted by following the modified method of Singh et al, 1990 [16] by extraction with chloroform and methanol in the ratio of $2: 1$. For the determination of ash content, moisture free sample was ignited at $550^{\circ} \mathrm{C}$ in a muffle furnace for about 2-3 hours to obtained carbon free white ash as described by AOAC, 2002 [2].

\section{Mineral analysis:}

Samples for mineral analysis were prepared according to recommendations of Perkin Elmer's, 1996 [26]. $2 \mathrm{gm}$. of mince fish sample was taken and dried at $135^{\circ} \mathrm{C}$ for 2 hours and weighed. It was heated up to $500-$ $550^{\circ} \mathrm{C}$ in a muffle furnace and obtained carbon free ash. It was added $2 \mathrm{ml} \mathrm{H}_{2} \mathrm{NO}_{3}$ and evaporated to dryness. $10 \mathrm{ml}$ $\mathrm{H}_{2} \mathrm{NO}_{3}$ was added and dissolved ash by heating continuously on a hot plate. It was transferred to a volumetric flask $(50 \mathrm{ml})$ and added $\mathrm{HCl}$ as necessary and 
diluted to volume with deionized distilled water (Millipore). All care was taken for cleanliness and non-contamination.

\section{Atomic absorption spectrometer analysis:}

Analysis of mineral elements $\mathrm{Ca}, \mathrm{Mg}, \mathrm{Na}, \mathrm{K}, \mathrm{Mn}$, $\mathrm{Ni}, \mathrm{Cu}, \mathrm{Zn}$ and $\mathrm{Fe}$ were done by Atomic Absorption Spectrometer 203 following the methods of Perkin-Elmer (1996) [26]. Most of the mineral elements $\mathrm{Na}, \mathrm{K}, \mathrm{Ca}$ etc. were done with hollow cathode lamps (HCL). Na and K were analyzed through Flame Photometer - 121,122,125.

\section{Statistical analysis:}

The data were subjected to one way-ANOVA and the significant mean were compared by Duncan's multiple range tests $(\mathrm{P}<0.05)$. Relationship between proximate composition and length-weight and essential mineral elements and length-weight were identified using Pearson's correlation coefficients. Differences and correlations were considered significance when $\mathrm{p}<0.05$ and $\mathrm{p}<0.01$ were obtained. Species were grouped and classified in a cluster by their similarities produce in the data. The linkage in dendrogram shows the order of dissimilarities designated as a distance index [35]. All the statistical analyses were performed using SPSS version 16.0.

\section{RESULT AND DISCUSSION:}

Proximate Composition and Macro and Micro elements of the three Cobitid Small Indigenous Fishes of Manipur namely Lepidochephalichthys guntea, Pangio pangia and Syncrossus berdmorei are shown in Fig. 5 and Table 3.

\section{Proximate analysis}

Results obtained from various analysis show that highest moisture content was found in $P$. pangia $(76.12 \pm 0.50 \%)$ which were followed by L. guntea $(71.21 \pm 1.08 \%)$ and lowest in $S$. berdmorei $(65.63 \pm 2.08 \%)$. The lower in the lipid content might be due to high lipid content in the fish [36]. The moisture ranging from 65.63 $\pm 2.08 \%$ to $76.12 \pm 0.50 \%$, which shows significance different $(\mathrm{p}<0.05)$ among the fishes, showing that percentage moisture content of all the fishes were under the acceptable level (50-80\%) [25].The knowledge of moisture content of food stuffs serves as a useful index of their keeping qualities and susceptibility to fungi infection [28].

Relatively higher protein to moderate level of protein content was shown in fishes studied. The highest protein content was found in S. berdmorei $(22.57 \pm 0.005 \%)$ and lowest was found in $P$. pangia $(10.79 \pm 0.40 \%)$. Fishes are the good sources of protein, but the differences observed might be owing to low potential of consumption or absorption capability and conversion potential of essential nutrients from their diet or local environment into a biochemical attributes needed by the fishes [31].
Lipids are highly efficient sources of energy and they contain more than twice the energy of carbohydrate and protein [19]. They serve as source of energy during starvation. In present study mean lipid content varies from $4.20 \pm 0.20 \%$ to $12.93 \pm 0.66 \%$ and shows a significance difference between the species $(\mathrm{p}<0.05)$. Highest lipid content was found in $S$. bermorei $(12.93 \pm 0.66 \%)$ and the lowest was found in L. guntea $(4.20 \pm 0.20 \%)$. According to Ackman, 1989, [27] fishes were grouped into four categories according to their fat content, lean fish $(<2 \%)$, low fat ( 2 to $4 \%$ ), medium fat (4 to $8 \%$ ) and high fat (> $8 \%)$. High lipid fishes have less water and more protein than low lipid fishes [36]. The low lipid content of the fish might be due to poor storage and the use of fat reserves during the spawning activity. The highest ash content was recorded in L. guntea $(3.23 \pm 0.07 \mathrm{mg} / 100 \mathrm{~g})$ and lowest in $P$. pangia $(1.57 \pm 0.06 \%)$ which shows significance difference ( $\mathrm{p}<0.05)$ between the species. Amount of ash content delineate the mineral content in food items. The observed ranges of the ash in all fishes indicate that they are good sources of mineral like potassium, calcium, manganese, magnesium, iron, zinc, etc. Higher content of ash may be due to higher bony consistency and highly scaly nature [6].

As reported by Deka et al., 2012 [3] variation in proximate composition of fish flesh may vary with species variation, season, age and quality of food. Besides this some physiological reasons and change in environmental condition might also greatly affect the proximate composition in fishes.

The relationship of moisture, protein, lipid and ash were stratified by total length and weight of the fishes (Table 2). From the analysis it was revealed that moisture content was negatively correlated with total length (-0.959), weight (-0.944), protein (-0.994), lipid (-0.697) and ash ($0.234)$. Whereas, protein content shows positive correlated with total length (.984), weight (0.974), lipid (0.770) and ash (0.128) except moisture (-0.994). Moreover lipid content was positively correlated with total length (0.873), weight (0.894), protein (0.70) but negatively correlated with moisture (-0.697) and ash (-0.534). However ash content was positively correlated with protein (0.128) only. Furthermore the correlation coefficient $\left(\mathrm{r}^{2}\right)$ of moisture, protein, lipid and ash with total length are $-0.959,0.984$, 0.873 , and -0.053 respectively. Whereas correlation coefficient $\left(\mathrm{r}^{2}\right)$ of moisture, protein, lipid and ash with weight were $-0.944,0.974,0.894$ and -0.098 respectively. From this analysis it can be revealed that larger the total length and weight, higher concentration of protein and lipid will be accumulated in the fishes. The cluster analysis dendrogram of proximate composition was depicted in Fig 6 which illustrate that L. guntea shows good similarities with $P$. pangio. Whereas $S$. berdmorei shows no similarities with other fishes studied 


$$
\text { C A S E }
$$

Lepidochephalichthys gtontea 1 Pangio pangia Synchrosstus berdmorei
Rescaled Distance Cluster Combine

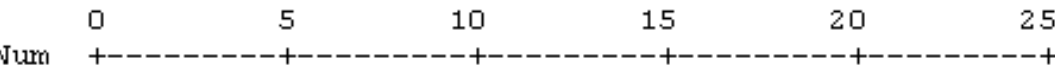

Fig 6: Dendrogram of Cobitids fishes using Ward's method with respect to proximate composition

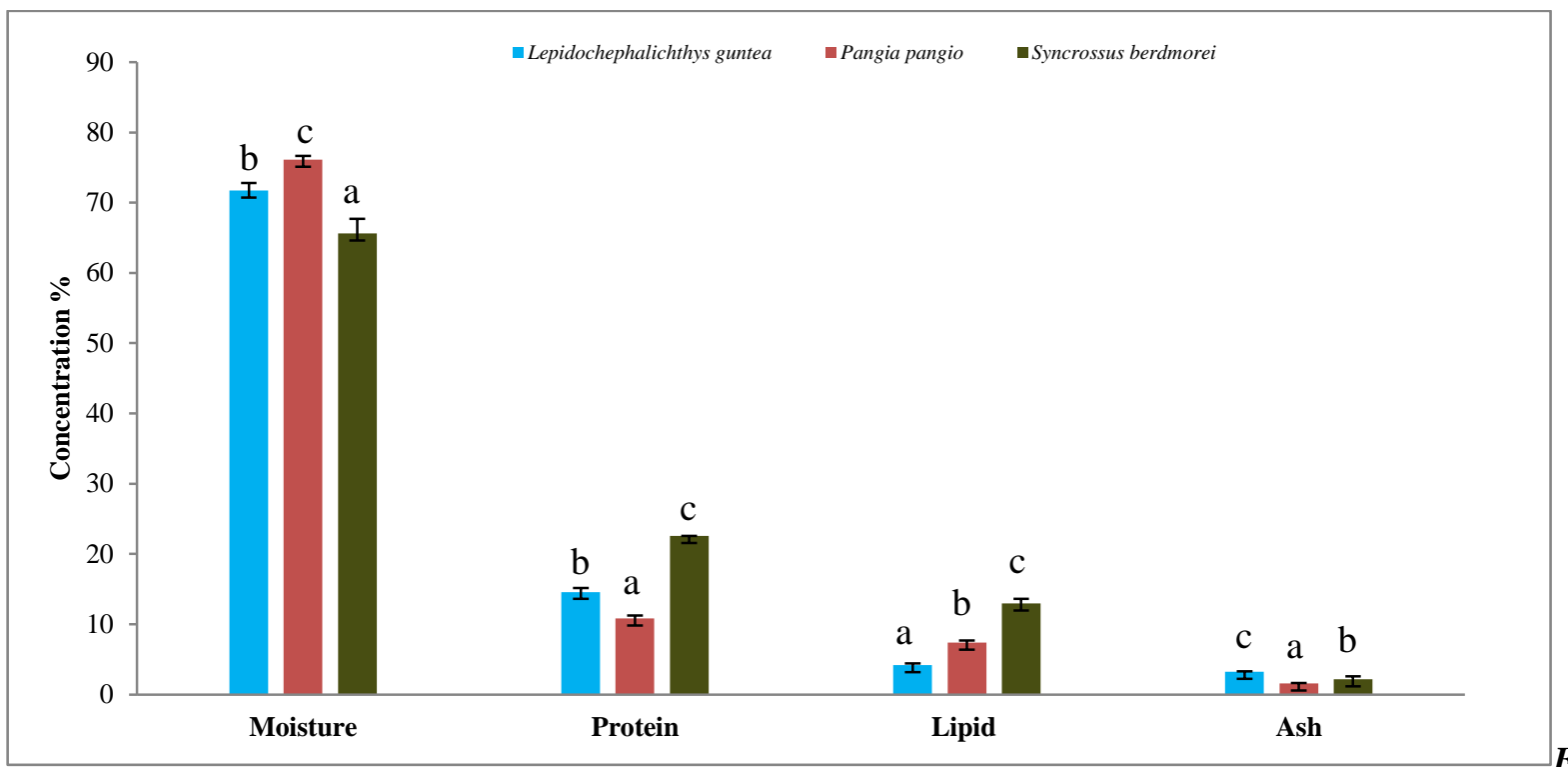

Proximate composition of three Cobitid fishes of Manipur. Means with different superscript shows on the bars are the significant difference by Dancan's multiple range test $(p<0.05)$.

Table 2: Pearson's correlation between proximate composition and total length-weight

\begin{tabular}{lrrrrrr}
\hline & Total length & \multicolumn{1}{l}{ Weight } & Moisture & Protein & Lipid & Ash \\
\hline Total & 1 & & & & & \\
length & & & & & & \\
Weight & 0.999 & 1 & & & & \\
Moisture & -0.959 & -0.944 & 1 & & & \\
Protein & 0.984 & 0.974 & -0.994 & 1 & 1 & \\
Lipid & 0.873 & 0.894 & -0.697 & 0.770 & -0.534 & 1 \\
Ash & -0.053 & -0.098 & -0.234 & 0.128 & & \\
\hline
\end{tabular}

*Correlation is significant at the 0.05 level

** Correlation is significant at the 0.01 level

\section{Minerals analysis}

The concentration of the studied minerals viz. macro elements $(\mathrm{K}, \mathrm{Na}, \mathrm{Ca}, \mathrm{Mg})$ and micro elements $(\mathrm{Fe}, \mathrm{Ni}, \mathrm{Zn}$, $\mathrm{Mn}, \mathrm{Cu}$ ) in three Cobitids fishes were shown in Table 3. A different concentration of minerals was detected and the concentration of macro and micro element in decreasing order as follows; $\mathrm{Ca}>\mathrm{K}>\mathrm{Mg}>\mathrm{Na}$ and $\mathrm{Fe}>\mathrm{Zn}>\mathrm{Ni}>\mathrm{Mn}>\mathrm{Cu}$ respectively. The comparison of three fishes by Duncan's One way ANOVA revealed that there were significantly different $(p<0.05)$ concentration in all the elements. Bhouri et al. (2010) reported in decreasing order of $\mathrm{K}>\mathrm{Na}>$ $\mathrm{Mg}>\mathrm{Ca}>\mathrm{Zn}>\mathrm{Fe}>\mathrm{Mn}>\mathrm{Cu}$ in muscle of wild Sea bass. The similar observation was shown by Abdul et al. (2012) in smoke dried Hill Stream Fishes of Manipur. Many researchers did not observed any definite order in magnitude of the elements. This variation in concentration of elements is due to the chemical forms of the elements and their concentration in the local environment [12].

The content of $\mathrm{K}$ and $\mathrm{Na}$ in all the fishes studied ranges from $87.33 \pm 0.29 \mathrm{mg} / 100 \mathrm{~g}$ to $90.81 \pm 1.14 \mathrm{mg} / 100 \mathrm{~g}$ and 
$45.0 \pm 0.20 \mathrm{mg} / 100 \mathrm{~g}$ to $112.5 \pm 0.06 \mathrm{mg} / 100 \mathrm{~g}$ respectively. Highest $\mathrm{K}$ and Na content were found in $S$. berdmorei and L. guntea respectively. The result of $\mathrm{K}$ was within the ranges and $\mathrm{Na}$ was lower than the previous report on the study of Puntius sophore of eastern Himalayas [5], they found that the content of $\mathrm{K}$ and $\mathrm{Na}$ is $82.24 \pm 0.10 \mathrm{mg} / 100 \mathrm{~g}$ and $208 \pm 0.14 \mathrm{mg} / 100 \mathrm{~g}$ respectively. The intake of $\mathrm{K}$ in both adult and children have an specific outcome in the maintenance of normal regulation of blood pressure, cardiovascular disease, coronary heart disease, stroke, renal function, blood lipid level, catecholamine level and potential adverse effect [34]. Moreover it also regulates the normal functioning of the nerves and muscles, the sugar metabolism, acid base balance and oxygen metabolism in the brain. Sodium regulates the electrolyte and acid-alkali balances, the conductive capacity of the nerves, muscle contractions and the production of adrenaline and amino acids. RDA of $\mathrm{K}$ and $\mathrm{Na}$ intake as safe and adequate are $1875-5625 \mathrm{mg} /$ day and $1100-3300 \mathrm{mg} /$ day respectively [21].

Concentration of $\mathrm{Ca}$ in all the fishes studied shows significantly difference $(\mathrm{p}<0.05)$ among the species. Highest Ca content was found in L. guntea $(2150.0 \pm 8.71$ $\mathrm{mg} / 100 \mathrm{~g}$ ). This report show higher concentration than the previous report on micronutrient content of fish species in Bangladesh [23], on their report they found the content of $\mathrm{Ca}$ in Small Indigenous Fishes in the range of $199 \mathrm{mg} / 100 \mathrm{~g}$ to $1061 \mathrm{mg} / 100 \mathrm{~g}$. Higher concentration of Ca might be due to the presence of the scales and bony nature of the fishes. Fish bone is rich in $\mathrm{Ca}$ but as fish bone is not necessarily eaten, the amount of bone discarded as plate waste must be adjusted for $\mathrm{Ca}$ content in edible part. However, in this fishes, higher concentration of $\mathrm{Ca}$ is due to the analysis of fishes as a whole. The amount of Ca content in Small fishes has higher value then the milk and the $\mathrm{Ca}$ in fish bone has the same bioavailability of milk [33]. Thus consumption of small fishes as a whole plays an important role as source of $\mathrm{Ca}$. For the positive $\mathrm{Ca}$ balance RDA of $\mathrm{Ca}$ intake in the adult should be in the ranges of 500-600 mg/day [21].

$\mathrm{Mg}$ is needed for bone, protein, and fatty acid formation, formation of new cells, vitamin B activation, muscle relaxation, blood clot formation, and energy metabolism [32]. Aquatic food products, like other animal products, are poor sources of $\mathrm{Mg}$. $\mathrm{Mg}$ concentration of fish species varies from $73.5 \pm 0.9 \mathrm{mg} / 100 \mathrm{~g}$ to $131.7 \pm 2.05$ $\mathrm{mg} / 100 \mathrm{~g}$ having a significantly difference $(\mathrm{p}<0.05)$ among the fishes. The concentration of $\mathrm{Mg}$ in L. guntea shows highest value among the species. Similar results were recorded in some hill stream fishes [10] as in the ranges of $82.00 \mathrm{mg} / 100 \mathrm{~g}$ to $131.20 \mathrm{mg} / 100 \mathrm{~g}$. The RDA for $\mathrm{Mg}$ in adult is 540 to $1000 \mathrm{mg} /$ day [21].

The highest Fe $(28.61 \pm 0.10 \mathrm{mg} / 100 \mathrm{~g})$ content was found in $S$. berdmorei and the lowest concentration was recorded in $L$ guntea $(13.55 \pm 0.26 \mathrm{mg} / 100 \mathrm{~g})$. In previous literature the Fe content have been reported in the ranges of $3.77 \mathrm{mg} / 100 \mathrm{~g}$ to $8.57 \mathrm{mg} / 100 \mathrm{~g}$ in fresh hill stream fishes of Manipur [10]. However, in small fishes of Bangladesh and Combodia the concentration of $\mathrm{Fe}$ is recorded in the ranges of $1.8 \pm 0.7 \mathrm{mg} / 100 \mathrm{~g}$ to $12.0 \mathrm{mg} / 100 \mathrm{~g}$ and $0.7 \pm 0.1 \mathrm{mg} / 100 \mathrm{~g}$ to $11.3 \pm 3.4 \mathrm{mg} / 100 \mathrm{~g}$ respectively [23]. In the present study the concentration of $\mathrm{Fe}$ is higher than that of the concentration reported by previous workers. This might be due to the availability of the Fe in local environment, diet, absorption capability and their preferential accumulation. Adequate $\mathrm{Fe}$ in the diet is very important for decreasing the incident of anaemia which is considered a major health problem especially in young children. Anaemia is also related to delayed cognitive development and intellectual impairment in children, reduces work capacity, risk of maternal mortality, as well as altered immune function [8]. The RDA for Fe of adult men in India is $5-35 \mathrm{mg} /$ day [21].

The maximum and minimum $\mathrm{Cu}$ content were $0.47 \pm 0.007 \mathrm{mg} / 100 \mathrm{~g}$ and $0.22 \pm 0.01 \mathrm{mg} / 100 \mathrm{~g}$ in L. guntea and S. berdmorei respectively. Abdul 2013 [10] has reported that the concentration of $\mathrm{Cu}$ in hill stream fishes is in the range of $0.299 \mathrm{mg} / 100 \mathrm{~g}$ to $1.50 \mathrm{mg} / 100 \mathrm{~g}$. Intake of $\mathrm{Cu}$ is essential for good health, however high intake of $\mathrm{Cu}$ may cause health problem such as liver and kidney damage and the deficiency of $\mathrm{Cu}$ may lead to various complicated diseases like anaemia, vascular complication, osteoporosis and neurological manifestation [21]. FAO/WHO, 1999 [9] has set a limit for heavy metal base on body weight of an average adult (60 $\mathrm{Kg}$ body weight), the provisional tolerable daily intake (PTDI) for $\mathrm{Pb}, \mathrm{Fe}, \mathrm{Cu}$ and $\mathrm{Zn}$ are 214 $\mu \mathrm{g}, 48 \mathrm{mg}, 3 \mathrm{mg}$ and $60 \mathrm{mg}$ respectively. The concentration of $\mathrm{Cu}$ content in fish samples shows within the range of limit intake [9]. The RDA for $\mathrm{Cu}$ intake of adult men in India is $2 \mathrm{mg} /$ day [21].

Deficiency of $\mathrm{Zn}$ manifest with symptom like growth failure, depress immunity, anorexia, diarrhea, altered skeleton function and reproductive failure [21]. Adequate intake of $\mathrm{Zn}$ has been found necessary to reduce childhood illness, enhance physical and decrease mobility, mortality in poor children [17] and also involved in most metabolic pathways in plants, animal and human. The concentration of $\mathrm{Zn}$ in all the fishes ranges from $1.40 \pm 0.01$ $\mathrm{mg} / 100 \mathrm{~g}$ to $3.05 \pm 0.014 \mathrm{mg} / 100 \mathrm{~g}$. Abdul (2013) [10] has reported in fresh hill stream fishes of Manipur in the ranges of $1.23 \mathrm{mg} / 100 \mathrm{~g}$ to $3.850 \mathrm{mg} / 100 \mathrm{~g}$. The RDA for $\mathrm{Zn}$ of adult Indian was $12 \mathrm{mg} /$ day [21].

The highest concentration of $\mathrm{Mn}$ and $\mathrm{Ni}$ in the fishes studied were $1.26 \pm 0.01 \mathrm{mg} / 100 \mathrm{~g}$ in $S$. berdmorei and $3.05 \pm 0.01 \mathrm{mg} / 100 \mathrm{~g}$ in $L$. guntea respectively. The results obtained were within the ranges of the concentration in hill stream fishes of Manipur [10]. The daily intake of $\mathrm{Mn}$ is needed for the growth of bone and good health in human, deficiency of Mn lead to problem of nervous system [7]. It 
also activates numerous enzyme including oxidoreductases, lyases, ligases, hydrolases, kinases, decarboxylases, and transferases. Ni aid in prolactin production thus involved in human breast milk production. It also helps in ions absorption as well as adrenaline and glucose metabolism, hormone, lipid, cell membrane, improves bone strength and may also play a role in production of RBC. However, occupational exposure to $\mathrm{Ni}$ may cause adverse health affect such as skin allergies, lung cancer and fibrosis [14]. The RDA of $\mathrm{Mn}$ is $2.5 \mathrm{mg} /$ day [21] and RDA of $\mathrm{Ni}$ for proper balance is $1 \mathrm{mg} /$ day [20].

Relationship between essential mineral elements and total length-weight of these fishes were presented in
Table 4.In these analyses, it is revealed that total length is positively correlated with $\mathrm{Fe}(0.813)$ which is followed by $\mathrm{Mn}$ (0.692) and K (0.688) respectively. These same elements were also positively correlated with weight of the fishes. However $\mathrm{Ca}, \mathrm{Mg}, \mathrm{Na}, \mathrm{Ni}, \mathrm{Cu}$ and $\mathrm{Zn}$ were negatively correlated with total length $(-0.502,-0.324$, $0.091,-0.553,-0.612$ and -0.470$)$ and weight $(-0.541$, $0.367,-0.137,-0.591,-0.648$ and -0.510$)$ of the small fishes suggesting that higher total length and weight may accumulates lower concentration of $\mathrm{Ca}, \mathrm{Mg}, \mathrm{Na}, \mathrm{Ni} \mathrm{Cu}$ and $\mathrm{Zn}$. The cluster analysis dendrogram with respect to mineral elements was shown in Fig 7 which illustrates that $P$. pangio shows good similarities with $S$. berdmorei. Whereas L. guntea shows no similarities with other fishes studied.

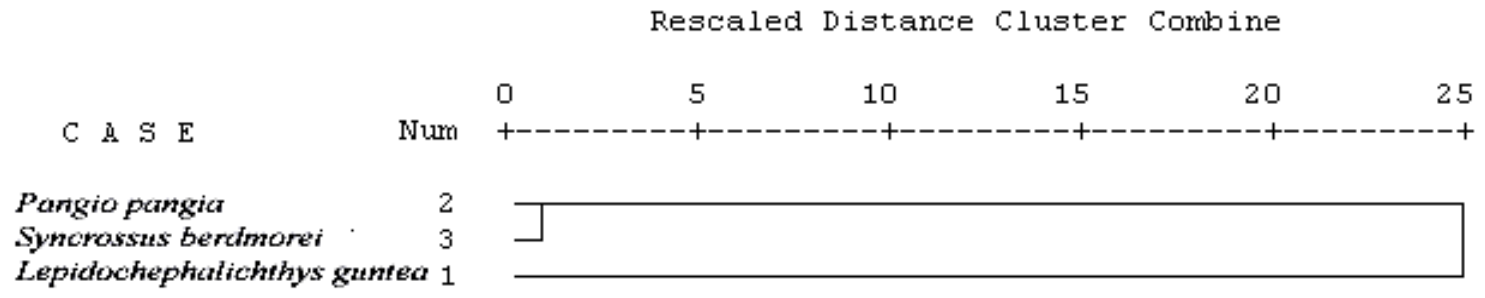

Fig 7: Dendrogram of Cobitids fishes using Ward's method with respect to Mineral elements

Table 3: Composition of the macro and micro element of three Small Indigenous Fishes

\begin{tabular}{|c|c|c|c|c|}
\hline & Nutrient content $\mathrm{mg} / 10 \mathrm{c}$ & & & \\
\hline & $\begin{array}{c}\text { Lepidochephalichthys } \\
\text { guntea }\end{array}$ & Pangio pangia & $\begin{array}{l}\text { Syncrossus } \\
\text { berdmorei }\end{array}$ & $\begin{array}{c}R D A \\
(m g / 100 g)\end{array}$ \\
\hline \multicolumn{5}{|l|}{ Macro elements } \\
\hline Calcium (Ca) & $2150.0 \pm 8.71^{\mathrm{c}}$ & $905.0 \pm 3.12^{\mathrm{b}}$ & $680.33 \pm 2.28^{\mathrm{a}}$ & $500-600 \%$ \\
\hline Magnesium (Mg) & $131.7 \pm 2.05^{\mathrm{c}}$ & $73.5 \pm 0.66^{\mathrm{a}}$ & $77.0 \pm 0.66^{\mathrm{b}}$ & $30-340 \%$ \\
\hline Sodium (Na) & $112.5 \pm 0.06^{\mathrm{c}}$ & $45.0 \pm 0.20^{\mathrm{a}}$ & $64.99 \pm 0.08^{\mathrm{d}}$ & $1100-3300 \%$ \\
\hline Potassium (K) & $87.33 \pm 0.29^{\mathrm{b}}$ & $57.5 \pm 0.15^{\mathrm{a}}$ & $90.81 \pm 1.41^{\mathrm{c}}$ & $1875-5625 t$ \\
\hline \multicolumn{5}{|l|}{ Micro elements } \\
\hline Manganese (Mn) & $1.15 \pm 0.005^{\mathrm{b}}$ & $0.27 \pm 0.009^{\mathrm{a}}$ & $1.26 \pm 0.01^{\mathrm{c}}$ & $2-5 t$ \\
\hline Nickel (Ni) & $2.25 \pm 0.029^{c}$ & $1.84 \pm 0.01^{\mathrm{a}}$ & $1.73 \pm 0.02^{\mathrm{b}}$ & $1.0^{*}$ \\
\hline Copper $(\mathrm{Cu})$ & $0.47 \pm 0.007^{\mathrm{c}}$ & $0.29 \pm 0.02^{b}$ & $0.22 \pm 0.01^{\mathrm{a}}$ & $2 \dagger$ \\
\hline Zinc (Zn) & $3.05 \pm 0.014^{c}$ & $1.59 \pm 0.011^{\mathrm{b}}$ & $1.40 \pm 0.01^{\mathrm{a}}$ & $12 \dagger$ \\
\hline Iron $(\mathrm{Fe})$ & $13.55 \pm 0.26^{\mathrm{a}}$ & $20.53 \pm 0.03^{\mathrm{b}}$ & $28.61 \pm 0.10^{\mathrm{c}}$ & $5-35 \dagger$ \\
\hline
\end{tabular}

Values are mean of three replicate.

Mean $( \pm \mathrm{SD})$ followed the same latter are not significantly different $(\mathrm{P} \leq 0.05)$.

†National Institute of Nutrition

*DRI: National Institute of Health, USA. 
Table 5: Pearson's correlation between essential mineral elements and total length-weight

\begin{tabular}{|c|c|c|c|c|c|c|c|c|c|c|c|}
\hline & $\begin{array}{l}\text { Total } \\
\text { length }\end{array}$ & Weight & Ca & Mg & $\mathrm{Na}$ & $\mathbf{K}$ & Mn & $\mathrm{Ni}$ & $\mathbf{C u}$ & $\mathbf{Z n}$ & $\mathbf{F e}$ \\
\hline $\begin{array}{l}\text { Total } \\
\text { length }\end{array}$ & 1 & & & & & & & & & & \\
\hline Weight & $0.999 *$ & 1 & & & & & & & & & \\
\hline $\mathrm{Ca}$ & -0.502 & -0.541 & 1 & & & & & & & & \\
\hline Mg & -0.324 & -0.367 & 0.981 & 1 & & & & & & & \\
\hline $\mathrm{Na}$ & -0.091 & -0.137 & 0.907 & 0.972 & 1 & & & & & & \\
\hline $\mathbf{K}$ & 0.688 & 0.654 & 0.282 & 0.464 & 0.660 & 1 & & & & & \\
\hline Mn & 0.692 & 0.659 & 0.276 & 0.458 & 0.655 & $1.0^{*}$ & 1 & & & & \\
\hline $\mathbf{N i}$ & -0.553 & -0.591 & $0.998 *$ & 0.967 & 0.880 & 0.224 & 0.218 & 1 & & & \\
\hline $\mathrm{Cu}$ & -0.612 & -0.648 & 0.991 & 0.947 & 0.843 & 0.147 & 0.147 & $0.97 *$ & 1 & & \\
\hline $\mathrm{Zn}$ & -0.470 & -0.510 & 0.999* & 0.987 & 0.922 & 0.311 & 0.311 & 0.995 & 0.986 & 1 & \\
\hline $\mathrm{Fe}$ & 0.813 & 0.839 & -0.912 & -0.814 & -0.654 & 0.143 & 0.143 & -0.935 & -0.958 & -0.896 & 1 \\
\hline
\end{tabular}

*Correlation is significant at the 0.05 level (2 tailed)

** Correlation is significant at the 0.01 level ( 2 tailed)

\section{CONCLUSION AND FUTURE SCOPE:}

From the above analysis, it can be conclude that Cobitid Fishes are good sources of protein, lipid and minerals $(\mathrm{Ca}$, $\mathrm{Mg}, \mathrm{Na}, \mathrm{K}, \mathrm{Mn}, \mathrm{Ni}$ and $\mathrm{Zn}$ ). Fish protein is known to be best animal protein source with high digestibility and good protein efficiency ratio. Fish lipid provide enormous amount of PUFA and MUFA especially Decosahexaenoic acid, Linoleic acid etc. which contribute to various health related benefit like lowering the risk of heart attack and stroke, developing eye and grey matter of brain and so on. They are also good sources of essential mineral elements which can combat various diseases like osteoporosis, night blindness, scurvy, hormone metabolism etc. This small fishes are consumed as a whole, thus can receive all the important nutrients which are benefit to maintain the heath, growth and development. It also provides the knowledge about the importance of Small Indigenous Fishes for their high nutritive value and good food for monitoring mineral deficiencies, so consumption of Small Indigenous Fishes should be encouraged.

Moreover further action is needed for conservation of small fishes. Many small fishes are in the verge of extinction due to ignorance of their nutritive value, destruction of habitat and feeding ground. Thus it required specific policy by the government and various research programmes and other related agencies to co-ordinate their effort for the conservation of these fishes. These small fishes are highly nutritious so, further research is highly needed to propagate these fishes to make easily available to the people.

\section{ACKNOWLEDGEMENT:}

Authors are grateful to Manipur University for financial assistant, to Head of Department, Department of Life
Sciences, Manipur University for providing laboratory facility for this analysis and Dr. N. Sanamacha Meetei, Investigator, R \& $\mathrm{D}$ Lab. Directorate of Environment, Government of Manipur , India for providing the Instrumental facilities and supporting in mineral analysis with Atomic Absorption Spectrometry.

\section{REFERENCES:}

[1] A.E. Andrew, "Fish processing technology", University of Horin Press, Nigeria, Pp. 7-8

[2] AOAC, Official Methods of Analysis. $16^{\text {th }}$ Edn. Association of official Analytical Chemists, Washington D.C., 2002.

[3] B.K. Deka, R. Mahanta and U.C. Goswami, "Seasonal variation of protein and Essential Amino acid contents Labeo gonius from Lotic and Lantic water bodies", World journal of Life sciences and Medicinal research. Vol. 2, Issue 2, Pp. 71, 2012.

[4] C. Sarojnalini, "Nutritive value of two indigenous Cobitid fishes Botia berdmorei and Lepidocephalus guntea of Manipur", The Bioscan, Vol. 2, Pp. 391-396, 2010.

[5] C. Sarojnalini and W. Sarjubala, (2014) "Antioxidant Properties and Nutritive Values of Raw and Cooked Pool Barb (Puntius sophore) of Eastern Himalayas", World Academy of Science, Engineering and Technology International Journal of Biological, Bio-molecular, Agricultural, Food and Biotechnological Engineering, Vol. 8, Issue 1, Pp. 8-12, 2014.

[6] C. Sarojnalini and W. Vishwanath, "Composition and nutritive value of sundried Puntius sophore", Journal of food science technology. Vol. 31, Issue 6, Pp. 75-78, 1994.

[7] D. Demirezen and K. Uruc, "Comparative study of trace elements in certain fish, meat and meat products" Meat Sciences, Vol. 74, Pp. 255-260, 2006.

[8] F. Camara, R. Barbera, M.A. Amora and R. Farre, "Calcium, Iron, Zinc and Copper transport and uptake by Calo-2 cell in school meals influences of protein and mineral interactions", Food Chemistry, Vol. 100, Issue 3, Pp. 1085-1092, 2007. 
[9] FAO/WHO, Expert committee on food additives. Summary and conclusions, 53rd meeting, Rome, 1-10 June, 1999.

[10] H. Abdul, Nutritional evaluation of some hill steam fishes of Manipur, (Unpublished doctoral thesis) Department of Life Sciences, Manipur University, Manipur, India, Pp. 109, 2013.

[11] H. Abdul and C. Sarojnalini, "Proximate composition, Macro and Micro minerals elements of some smoke-dried hill stream fishes from Manipur, India”, Nature and Science, Vol. 10, Issue 1, Pp.59-65, 2012.

[12] H. Window, D. Stein, R. Scheldon and J. R. Smith, "Comperation of trace metal concentration in muscle of a benthopelagic fish Coryphaenoidae armatus from Atlantic and Pacific Ocean", Deep Sea Research, Vol. 34, Pp. 213-220, 1987.

[13] J.J. Watchmen, "Composition and quality of fish, Edinburge", Torry Research Station, 2000.

[14] K. Satish and A.V. Trivedi, "A reviews on role of Nickel in the biological system", International Journal of Current Microbiology and Applied Sciences, Vol. 5, Issue 3, Pp. 719-727, 2016.

[15] M.A. Bhouri,I. Bouhlel, L. Chouba, M. Hammami,M.E. Cafsi, and A. Chaouch, "Total lipid content, fatty acid and mineral compositions of muscles and liver in wild and farmed sea bass (Dicentrarchus labrax)", African Journal of Food Science, Vol. 4 Issue, 8, Pp. 522-530, 2010.

[16] M.B. Singh, C. Sarojnalini, and W. Vishwanath, "Nutritive values of sundried Esomus danricus and smoked Lepidocephalus guntea", Food Chemistry, Vol. 36, Pp. 89-96, 1990.

[17] M.K. Bhan, H. Sommerfelt and T. Strand, "Micronutrient deficiency in children", British Journal of Nutrition, Vol. 85, Pp. S199-S203, 2001.

[18] M. Kottelat, "Fishes of Laos" WHT Publication (Pte) Ltd. ISBN 955-9114-25-2, 2001.

[19] M. Okazumi and T. Fujii , "Nutritional and functional properties of squid and cuttle fish", $35^{\text {th }}$ Anniversary commemorative publication, Pp. 223, 2000.

[20] National Institute of Health, "DIETARY REFERENCE INTAKES for Vitamin A, Vitamin K, Arsenic, Boron, Chromium, Copper, Iodine, Iron, Manganese, Molybdenum, Nickel, Silicon, Vanadium, And Zinc", National Academy of Sciences, USA., Pp. 527,2001

[21] National Institute of Nutrition,"Nutrient requirements and recommendation dietary allowances for Indian", Indian council of Medical research, 2009.

[22] N. Louka, F. Juhel, V. Fazilleau and P. Loonis, "A novel colorimetry analysis used to compare different drying fish process", Food Control, Vol. 15, Pp. 327-334, 2004.

[23] N. Roos, M.A. Wahab, C. Chamnan and, "The role of fish in food based strategies to combat Vitamin A and mineral Deficiencies in Developing countries", Journal of Nutrition, Vol. 137, Pp. 1106-1109, 2007.

[24] N. Roos, T. Leth, J. Jakobsen and S. H. Thilsted, "High vitamin A content in some small indigenous fish species in Bangladesh: perspectives for foodbased strategies to reduce vitamin $A$ deficiency", International Journal of Food Sciences and Nutrition, Vol. 53, Pp. 425-437, 2002.

[25] O. Abbas, M. Aliyu, M.S. Bello, M. Aminu, M.H. Abdullahi, M. T. Kasirat, Nutrient Composition of Tilapia zilli, Hemisynodontis membranacea, Clupea harengus and Scomber scombrus
Consumed in Zaria, World Journal of Life Sciences and Medical Research, Vol. 2, Issue. 16, 2012.

[26] Perkin-Elmer, "Analytical methods of Atomic Absorbtion Spectroscopy", The Perkin Elmer Inc.USA, 1996.

[27] R.G. Ackman, "Nutritional composition of fats in seafoods",Progress in Food and Nutritional Science, Vol. 13, Pp. 161-241, 1989.

[28] S.O. Bassey, M.U. Eteng, E.U. Eyong, O.E. Ofem, E.O. Akunyoung, and I. B. Umoh, "Comparative nutritional and biochemical evaluation of Ergeria radiata (clams) and Pomecia palludosa (gastropods)", Research Journal of Agricultural and Biological Science Vol. 7 Issue 1, Pp. 98-104, 2011.

[29] S.H. Thilsted, N. Roos, and H. Nazmul, "The role of Small Indigenous Fish species in food and nutrition security in Bangladesh", World Fish Center, Naga, the ICARM Quarterly, July-December (Supplement), Pp. 82-84, 1997.

[30] S. Kumar and A.V. Trivedi, "A Review on Role of Nickel in the Biological System", International Journal of Current Microbiology and Applied Sciences, Vol. 5, Issue 3, Pp. 719-727, 2016.

[31] S.O Adewoye, and J.S. Omotosho, "Nutrient composition of some freshwater fishes in Nigeria", Bioscience Research Communication, Vol. 11, Issue 4, Pp. 33-336, 1997.

[32] S.P. Lall, "Macro and trace elements in fish and shellfish. In: Ruither, A., Ed., Fish and Fishery Products: Composition, Nutritive Properties and Stability", USA, CAB International, Pp. 187-214, 1995.

[33] T. Lersen, S. H. Thilsted, K. Kongsbak, and M. Hansen, "Whole small fish as a rich calcium source”, British Journal of Nutrition, Vol. 83, Pp. 191-196, 2000.

[34] WHO, "Guideline of potassium intake for adult and children", WHO. Pp 10, 2012.

[35] W.I. Krzanonshi, "Multivariate analysis" Oxford University press, USA, 1995.

[36] W. Steffens, "Freshwater fish-wholesome food stuff" Bulgarian journal of Agricultural Science, Vol. 12, Pp. 320-328, 2006.

[37] W. Vishwanath, W.S. Lakra and U.K. Sarkar, "Fishes of North East India", National Bureau of Fish Genetic Resourse, Lucknow (NBFGR), ISBN, 978-81-905540-1-5, 2007.

\section{AUTHORS' PROFILE}

Dr. Ch Sarojnalini was pursued her B.Sc degree in Zoology honour Gauhati University 1979; M.Sc. In Life Sciences, Fishery specialization J.N.U Centre, Imphal 1982, Ph.D. in Fish and Fisheries from Manipur University in 1989 and faculty of Manipur University (A Central University). She is currently working as an Associate Professor in Department of Life Sciences, Manipur University since 1998. 5 students

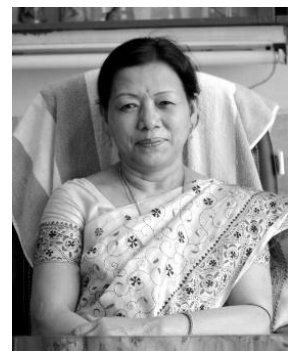
were awarded Ph.D. at present 6 students are pursuing Ph.D. under her supervision. She has published more than 40 papers in international and national peer-reviewed Journals and published 8 book chapters. She has participanted and presented more than 50 research papers in oral and poster in different national and international conferences, seminars, etc. She attained more than 10 
workshop and training in different parts of the country. She was awarded Gold Medal for best paper presentation in $6^{\text {th }}$ All India Seminar on Ichthyology, 1986 by Academy of Ichthyologists, UP and awarded Research Associate under CSIR and UGC in the year 1989 and 1993 respectively. She was the reviewer of European Food Research and Technology, Springer and life members of the Journal of Food Science \& Technology, Mysore, Society of Fisheries Technologists (India), Cochin, Diractorate of cold water fisheries, ICAR, Bhimtal, Inland Fishery Society of India, Barrackpore, Kolkata, Zoological Society of India, Kolkata, Aquatic Biodiversity Conservation Society, India, Lucknow, Ichthyological Society of Japan, Japan and ISCA, Kolkata. Her research interested areas are Biochemical aspects of fresh and processed fishes of plain and hill stream fishes and also in fish processing technology especially in fermentation of fish.

Shantosh Mayanglambam was pursued his B.Sc (Zoology Honours) in 2008 from North Eastern Hill University, Shillong, Meghalaya and M.Sc. Specialized in Fish and Fishery Manipur University, Canchipur, Manipur in the year 2011. He cleared CSIR-NET conducted by CSIR in the year 2011. He pursues his Ph.D. under the supervision of Dr. Ch. Sarojnalini, in the Department of Life Sciences, Fishery

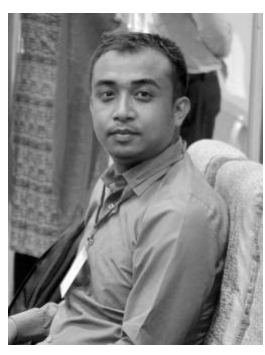
Laboratory, Manipur University. He has published 2 research papers in peer reviewed journals, participant and presented research papers in 1 international conference and 3 national seminars including ISCA. He attained 3 workshops and training in fish taxonomy, operation and troubleshooting in HPLC, GC-MS and LCMS, Biotech Park, Assam etc. He is interested in the research areas of biochemical assessment, Biology and conservation of Small Indigenous Fishes. 